\title{
Strict Liability for Environmental Offenses
}

\author{
Al Halim ${ }^{1}$, Mahrus Ali ${ }^{2}$ \\ $\left\{\right.$ halim_not@yahoo.co.id ${ }^{1}$, mahrus_ali@uii.ac.id $\left.{ }^{2}\right\}$ \\ Doctorate Program Student in Law Diponegoro University, Semarang, Indonesia ${ }^{1}$ Universitas Islam \\ Indonesia, Yogyakarta, Indonesia ${ }^{2}$
}

\begin{abstract}
This study aims to analyze the rationality and application of strict liability for environmental offenses in the Environmental Protection and Management Act of Indonesia. The strict liability set out in this law expressly applies only to civil cases and covers the possibility that it may be used in criminal matters. Normative legal research complemented by a statutory and conceptual approach was used. The results showed that it generally applies to regulatory offenses aimed at protecting the public interest. This doctrine is necessary to improve the long-term and prevents harm to people or the environment. The absence of mental element proof should be limited to offenses that are characterized by the administrative dependence of criminal law, which is reflected in the abstract and concrete endangerment models. The offense is formulated as formal offense by eliminating the element of the perpetrator's culpability, and it is therefore not necessary to prove it.
\end{abstract}

Keywords: Strict liability; Regulatory offenses; Administrative dependent of criminal law; Environmental harm.

\section{Introduction}

Generally, a crime consists of both physical and mental elements. The first is characterized by active (commission) or passive actions (omission), the way they are performed, the consequences that cause damage, and the circumstances associated with the execution of prohibited actions [1]. The second refers to culpability of the actors that take various forms in an offense formula such as intentionally, with intent, knowingly, willfully, recklessly, or with criminal negligence [2]. This mental element can only be directed towards actions and their consequences which is obtained in most Modern Criminal Code. In its development, mental elements are not required in imposing criminal sanctions. In certain cases based on the concept of strict liability, the defendant can even be held liable and convicted of an act committed without the need of proving guilty [3].

Furthermore, it is often associated with public welfare offense (regulatory offenses) which eliminates the element of perpetrators' fault to protect the public from avoiding danger. However, this concept is characterized by mild criminal threats, low community stigma, and generally includes arrangements related to industry activities [4]. Precisely, there are eight types of criminal activities including regulatory offenses, such as a) illegal sales of intoxicating liquor, b) sales of impure or adulterated food or drugs c) sales of misbranded articles, d) violations of anti-narcotics acts, e) criminal nuisances (consisting of annoyances or injuries to public health, safety, repose or comfort, obstructions of highways), f) violations of traffic regulations, g) violations of motor-vehicle laws, and $\mathrm{h}$ ) violations of general police 
regulations, passed for the safety, health, or well-being of the community [5]. This study analyzes the application of strict liability in environmental crime. This is important because its provision in Law Number 32 Year 2009 concerning Environmental Protection and Management Act (EPMA) only applies to civil cases as formulated in Article 88. Meanwhile, most of the offenses against this law are essentially an administrative violation which in the formulation does not include a mental element of crime [6].

The first part of this study explores the theoretical concept of strict liability in criminal law. However, not all experts agree to apply it but can still be used for certain criminal acts. The second part explains the reasons for its application in environmental offenses, which requires intertwining between administrative and criminal law [7]. Most of them are also related to administrative violations such as permits.

The last part analyzes the application of strict liability to environmental offenses. The research argues that the concept of res ipsa loquitor (the thing speaks for its self) is inadequate to serve as a basis for applying it to environmental offenses. However, the EPMA includes an intentional element that was formulated materially. Therefore, the study offers a strict liability implementation in the context of the criminalization models based on environmental harms, especially abstract and concrete endangerment. In both models, violations threatened by criminal sanctions are generally related to administrative violation since it does not require damages.

\section{Methods}

This study is a normative legal study that focuses on the application of strict liability for environmental offenses in EPMA. The offense formulation in the Act is reviewed and selected following its regulatory character since the mental element has the potential not to be proven. This study is complemented by the use of a statutory and conceptual approach, of which the first shows legal norms that contain the offense formulation. However, to know which offenses do not require proof of perpetrators, the strict liability doctrine and criminalizationbased environmental loss models should be examined, especially abstract and concrete endangerment. Furthermore, legal issues in studies are analyzed qualitatively through data reduction, presentation, and conclusions used simultaneously.

\section{Result and Discussion}

\subsection{The Nature of Strict Liability}

Strict liability does not need to prove the perpetrator's culpability against one or more of the actus reus [8] since it is no longer considered as partial or total crimes. However, the fact that a commission or an omission offense has been committed needs to be proven. Within the criminal law, it is used for crimes that do not require the perpetrator's fault or a mental element following its occurrence [9].

L.B. Curzon argues that there are several reasons why this element should not be proven since ensuring respect for the rules guiding the good of the community is important. Therefore, proving the existence of criminal action (mens rea) will be difficult for violations related to social welfare due to the high level of danger posed by the act in question [10]. 
There are many factors of the legislators which determine the use of strict liability in criminal law, because of, (1) characteristics of a crime, (2) threatened punishment, (3) the absence of social sanctions (obloquy) (4) certain damage caused, (5) scope of activities performed, and (6) the formulation of certain verses and their context in law [11]. These six factors demonstrate the importance of public concern in behaviors that need to be avoided by applying strict liability to public safety, the environment, and economic interests, including consumer protection [12].

Strict liability is most often used for public welfare offenses where criminal sanctions are generally mild such as fines and short imprisonment [13]. It is applied when the court concludes that the evidence of the action element leads to a definitive conclusion of finding it hard to prove the perpetrator's culpability. However, in cases related to violations of public welfare or regulatory offenses, the difficulty in proving is the basis for justifying the application of strict liability, in addition to the fact that the violated act is under public rules that have serious threats to health and safety [14].

The doctrine of the public welfare offense was formed during the industrial revolution to impose tougher obligations on industry, commerce, property, or other activities that have an impact on public health, safety, and welfare. Strict liability requires two driving factors to improve the implementation of regulatory offenses. First, individual fault-proof requirements will weaken the burden of the criminal justice system. Second, in many violations of regulatory offenses, the fault-proof is quite difficult. Since the existence of some new types of criminal acts is not intentionally required, legislators begin to criminalize regulatory offenses although limited to certain areas [15].

Strict liability is based on three objectives. First, social objectives such as healthy and clean food and drinks, surviving fires, workplace safety as well as in traffic orientation. Second, they can be better achieved through the types of criminal acts that do not require to prove the perpetrator's culpability to maximize social prevention. Third, strict liability is assumed only based on utilitarianism, when the criminal threat for a corresponding crime is low [16].

One of the goals of criminal law is to prevent loss in society. The criminal justice system seeks to convict perpetrators that socially violate the 'normal' behavior [17]. In this context, strict liability is primarily based on the utilitarianism argument of promoting effective regulation of activities in various public and important places [13]. Furthermore, it causes people to be more careful in their behavior to prevent the effect of (one's) actions in the future. It also creates a high standard of public behavior in the hope that the public will show increased responsibility and behave more cautiously in certain areas. Therefore, it can prevent harm to others or property [13].

Not all experts agree that strict liability is used in criminal cases with the reason that they do not require the perpetrators' mistakes proof since they cause controversy [18]. In addition, it violates the fundamental principles of criminal law, where the imposition of its sanctions is only valid when the defendant's mistake has been proven [2]. Therefore, even though strict liability will be applied in criminal cases, it should be limited only to offenses in the malum prohibitum category, because the evil nature of an act is not inherent, solely because the law prohibits [19].

\subsection{Rationale for Strict Liability}

Strict liability is regularly used in the environmental offense, and this is justified by several reasons. This offense can lead to long term dangers and they are difficult to repair directly or indirectly. This danger shifts the focus from protecting individual to public 
interests. However, the use of strict liability in this context only transfer full responsibility of the hazard to people that can prevent the loss [20].

Hazardous and toxic waste (B3) discharged into the environment without authorization can potentially have uncontrolled effects with $\mathrm{B} 3$ migration below the surface. It harms human health and the environment. The application of strict liability is justified because unauthorized storage and disposal of B3 waste, regardless of the precautions taken, can lead to enormous environmental losses in the form of water pollution [21]. The absolute responsibility to think and have knowledge of these actions can potentially harm others or the environment, such as damage and degradation of ecosystems, species extinction, climate change, and global warming, environmental pollution, as well as the increased mortality rate in animals [22]. B3 waste discharged into the environment through safety procedures and processes also increases the incidence of respiratory illnesses and reduces the overall quality of the earth's atmosphere. The impact can be felt long after the perpetrators dispose these materials [23].

Strict liability on environmental offenses is also based on the argument that the legal interests to be protected are not only humans and the environment but also future generations. The current generation does have full control over all the natural resources on earth. However, the right of future generations to have equal rights and access to healthy environmental quality should not be compromised. [21]Meanwhile, the environment is also considered as an independent legal interest since it is a victim of crime, therefore, humans need to obey nature (the environment) [24].

The offenses in the EPMA are mostly related to violations of administrative obligations such as authorization. Therefore, it depends on fulfilling the conditions set by or the provisions contained in administrative regulations set out in Articles 100, 101, 102, 103, 104, $109,110,111$, and 114. The offenses are categorized as administrative dependent crimes for three reasons. First, it is a formal offense that focuses on the prohibited acts, and not the consequences. Second, the prohibited actions are not shameful, but because they are prohibited by law (legally wrong). Third, the essence of offense in this study relates to violation permits for authorization. Therefore, the administrative nuance is thicker since some requirements need to be fulfilled prior to performing certain actions. Violations of these requirements are categorized as criminal offenses [25].

Mental/mistakes elements were not explicitly stated in the offenses formulation, and they are considered to be proven by the prohibited acts. Therefore, there is no obligation for the public prosecutor to prove the mental element. Its absence in the strict liability context requires everyone including corporations to be more careful in performing actions that can endanger the environment [20].

\subsection{Applying Strict Liability for Environmental Offenses}

Environmental offenses stipulated in the EPMA consist of formal and material delict. Formal offenses are regulated from Articles 100 to 111 and from Articles 113 to 115, and they are mostly administrative-dependent. On the contrary, material offenses are regulated in Articles 98, 99, and 112. The criminal law in the first two articles has been separated from the administrative independence of environmental criminal law. When the perpetrator's actions have caused environmental damage or pollution, criminal sanctions can be imposed immediately even though they are not against the law.

Strict liability can be applied to formal offenses with substance in the form of administrative's violation requirements such as a permit/license. However, its implementation in material offenses will cause some problems. In many cases, environmental damage or pollution only occurs long after the prohibited acts have been committed. It is very difficult to 
prove the causal relationship (causality) in environmental cases because they are varied, chained, and complex as well as involving many variables especially in pollution [26]. The criminal threat in material offenses at the EPMA is also very severe in the form of imprisonment years of at least 5 and at most 15 as well as fines of at least 5 billion and a maximum of 15 billion. The severity of this criminal threat contradicts the strict liability character that mostly related to regulatory offenses.

According to the study, its implementation needs to pay attention to the criminalization models-based on environmental harm, especially the abstract and concrete endangerment models since they do not require to prove culpability of the actors. The prohibited actions on both models are all formulated as formal offenses, while the substance is in the form of administrative requirements' violation. The first model criminalizes offenses towards administrative obligations [27]. The criminal law is enforced immediately after violating an administrative law sequel to the occurrence of a real loss or threat of violation. This model restricts criminal acts without involving direct contact between contaminated material and the environment [26].

Environmental offenses of the first model include 'conducting business activities (UKLUPL) without having an environmental permit in Article 109', 'preparing EIA without having a competency certificate of its compiler in Article 110', and 'issuing an environmental permit without being equipped with UKL-UPL (Environmental Management Efforts (UKL) and Environmental Monitoring Efforts (UPL)) or issuing a business authorization without being equipped with an environmental permit in Article 111 '. However, the offenses without involving direct contact between contaminated material and the environment do not require proof of loss threat.

The second model does not require proof of actual loss, but sufficient in proving the threat of loss and actions performed unlawfully [28]. Criminalization in this model is performed to prevent the loss of both humans and the environment [29]. Therefore, this model emphasizes that emissions or pollution can cause damage and need to be proven since they are performed unlawfully. As long as the administrative regulations are followed, the law is not considered a criminal offense when it is legally enforced. In contrast, it is qualified as a crime when committed illegally [30]. Furthermore, it directly protects ecological values, but its existence depends on administrative regulations [30]

The offenses in the second model criteria include 'releasing and distributing genetic engineering products to environmental media that contradict the permit in Article 101', 'violating the wastewater and emission-quality standard in Article 100', 'conducts B3 waste management without permission in Article 102', 'produces B3 waste and does not conduct management in Article 103', and dumps waste material into the environmental media without permission in Article 104'. These offenses relate to direct contact between the contaminated material and the environment. Furthermore, there is evidence that actions are performed against the law and threaten environmental damage/pollution.

Strict liability can be applied to these offenses considering that they have been formulated as formal offense that do not require the causation. The absence of a criminal offense also depends on administrative requirements. Therefore, the administrative nuance is very thick with regulatory offenses, and it does not include mental elements such as intention or negligence. In addition, the defendant can be convicted when proven guilty of prohibited acts without authorization. The method of formulating prohibited acts also shows that the intentions of the perpetrators already exist when they commit them. Although, it does not need to be proven, such as managing B3 waste, and dumping it to environmental media without 
permission. These actions are generally performed by corporations since they have the potential to harm both humans and the environment.

\section{Conclusion}

Strict liability is often used in offenses aimed at protecting public interests which endanger human safety/health and the environment. The use of this doctrine on environmental offenses correlates with its position as an independent legal interest that prioritizes the prevention of hazards. Also, the implementation of strict liability needs to be limited in the EPMA only to offenses dependent on the criminal law as in the abstract and concrete endangerment models. Their offenses are generally related to waste/emissions discharged into the environmental media without permission. They are also formulated as formal offenses, where the perpetrators' mental element is not included in the formula. Therefore, it does not need to be proven.

\section{References}

[1] R. Sanders, "The Knowledge Element in Drug Cases: Some Final thoughts on Shelton and Adkins," Florida bar Journal, vol. 88, p. 42, 2014.

[2] M. Bohan, " Complicity Strict Liability: A Logical Inconsistency?," University of Colorado Law Review, vol. 86, pp. 634-635, 2015.

[3] G. Luzon, "Challenges Shared by Restorative Justice and Strict Liability in the Absence of Mens Rea," New Criminal Law Review, vol. 19, p. 583, 2016.

[4] G. S. Moohr, "Moohr, Geraldine Szott: Playing with the Rules: An Effort to Strengthen the Mens Rea Standards of Federal Criminal Laws," Journal of Law, Economics \& Policy, vol. 7, pp. 696697, 2011.

[5] R. Libman, "Is Presuming Guilt for Regulatory Offences still Constitutional but Wrong? R v Wholesale Travel Group Inc and Section 1 of the Charter of Rights and Freedoms 20 Years After," Ottawa Law Review, vol. 43, p. 459, 2012-2013.

[6] H. A. a. M. Ali, Theory of Criminal Liability Its Development and Application, Jakarta: Rajawali Press, 2015.

[7] M. G. F. e. all, "Faure, Michael G. et all: Imposing Criminal Liability on Government Officials under Environmental Law: A Legal and Economic Analysis," Loyola of Los Angeles International and Comparative Law Journal, vol. 18, p. 558, 1996.

[8] R. Heaton, Criminal Law Textbook, London: Oxford University Press, 2006.

[9] W. R. Thomas, "On Strict Liability Crimes: Preserving a Moral Framework for Criminal Intent in an Intent-Free Moral World," Michigan Law Review, vol. 110, p. 650, 2012.

[10] L. Curzon, Criminal Law, London: Mac Donald \& Evans Limited, 1973.

[11] Y. Shofie, Corporate Criminal Liability in Indonesia Consumer Protection Law, Bandung: Citra Aditya Bakti, 2011.

[12] Y. Shofie, Corporate Criminal Liability in Indonesia Consumer Protection Law, Citra Aditya Bakti: Bandung, 2011.

[13] G. Luzon, "Challenges Shared by Restorative Justice and Strict Liability in the Absence of Mens Rea," New Criminal Law Review, vol. 19, p. 604, 2016. 
[14] D. K. Brown, "Strict Liability in the Shadow of Juries," SMU Law Review, vol. 67, pp. 535-536, 2014.

[15] R. A. Lyons, "Florida's Disregard of Due Process Rights for Nearly a Decade: Treating Drug Possession as a Strict Liability Crime," Saint Thomas Law Review, vol. 24, pp. 359-360, 2012.

[16] M. S. Moore, " The Strictness of Strict Liability," Criminal Law and Philosophy, vol. 12, p. 521, 2018.

[17] B. Kimberly, "Shot through the Heart: The FDA Give all Health Care Company Executives a Bad Name under the Controversial Strict Liability Misdemeanor Provision of the Federal Food, Drug, and Cosmetic Act," Brooklyn Journal of Corporate, Financial \& Commercial Law, vol. 6, p. 602, 2012.

[18] J. Fershee, "Choosing a Better Path: The Misguided Appeal of Increased Criminal Liability after Deepwater Horizon," William and Mary Environmental Law and Policy Review, vol. 36, p. 5, 2011.

[19] V. Bergelson, "A Fair Punishment for Humbert: Strict Liability and Affirmative Defenses," New Criminal Law Review, vol. 14, pp. 60-61, 2011.

[20] K. Robbins, "Paved with Good Intentions: The Fate of Strict Liability under the Migratory Bird Treaty Act," Environmental Law, vol. 42, p. 594, 2012.

[21] J. R. MacAyeal, "The Comprehensive Environmental Response, Compensation, and Liability Act: The Correct Paradigm of Strict Liability and the Problem of Individual Causation," UCLA Journal of Environmental Law \& Policy, vol. 18, p. 243, 2000/2001.

[22] J. G. Laitos, "Standing and Environmental Harm: The Double Paradox," Virginia Environmental Law Journal, vol. 31, pp. 67-71, 2013.

[23] N. S. a. A. S. Routhe, "Environmental Crime," Crime and Justice, vol. 32, pp. 323-324, 2005.

[24] M. C. Wood, Nature's Trust Environmental Law for a New Ecological Ag, New York: Cambridge University Press, 2014.

[25] F. Picinali, "The Denial of Procedural Safeguards in Trials for Regulatory Offences: A Justification," Criminal Law and Philosophy, vol. 11, p. 685, 2017.

[26] S. F. M. a. M. G. Faure, "Mandiberg, Susan F. \& Faure, Michael G: A Graduated Punishment Approach to Environmental Crimes: Beyond Vindication of Administrative Authority in the United States and Europe," Columbia Journal of Environmental Law, vol. 34, p. 478, 2009.

[27] M. F. a. M. Nisser, "Faure, M. \& Nisser, M: How to Punish Environmental Pollution- Some Reflections on the Various Models of Criminalization of Environmental Harm," European Journal of Crime, Criminal Law and Criminal Justice, vol. 3, p. 319, 1995.

[28] M. Faure, "Towards a New Model of Criminalization of Environmental Pollution: The Case of Indonesia. In Faure, Michael \& Niessen, Nicola (Editor)," in Environmental Law in Development Lesson from the Indonesia Experience, United Kingdom, Edward Elgar Publishing Limited, 2006, p. 197.

[29] Z. Hoskins, "Hoskins, Zachary: Criminalization and the Collateral Consequences of Conviction," Criminal Law and Philosophy, vol. 12, p. 634, 2018.

[30] M. Faure, "The Revolution in Environmental Criminal Law in Europe," Virginia Environmental Law Journal, vol. 35, p. 335, 2017.

[31] B.-S. Cho, "Cho, Byung-Sun: Emergence of an International Environmental Criminal Law?," UCLA Journal of Environmental Law and Policy, vol. 19, pp. 22-23, 2000/2001.

[32] R. Sanders, "The Knowledge Element in Drug Cases: Some Final thoughts on Shelton and Adkins.," Florida bar Journal, vol. 88, p. 42, 2014.

[33] M. Faure, "The Revolution in Environmental Criminal Law in Europe," Virginia Environmental Law Journal, vol. 35, p. 335, 2017. 